\title{
THE OCCURRENCE OF ARBUSCULAR MYCORRHIZAL FUNGI OF THE PHYLUM GLOMEROMYCOTA IN ISRAELI SOILS
}

\author{
JANUSZ BŁASZKOWSKI, BEATA CZERNIAWSKA \\ Department of Plant Pathology, University of Agriculture \\ Słowackiego 17, 71-434 Szczecin, Poland \\ e-mail: jblaszkowski@agro.ar.szczecin.pl \\ http://www.agro.ar.szczecin.pl/ jblaszkowski/ \\ http://www.agro.ar.szczecin.pl/ jblaszkowski/Mycota/
}

(Received: March 15, 2006. Accepted: May 20, 2006)

\begin{abstract}
In December 1997 and June-July 2000, 49 and 113 rhizosphere soil and root mixtures were collected, respectively, to determine the occurrence of arbuscular mycorrhizal fungi (AMF) of the phylum Glomeromycota in different sites of Israel. Except for five samples taken from under cultivated plants, all the others came from under Ammophila arenaria and Oenothera drummondii colonizing sand dunes adjacent to the Mediterranean Sea. After a continuous cultivation of the mixtures in pot trap cultures with Plantago lanceolata as the plant host up to 2006 and their examination at least twice a year, spores of AMF were found in 41 and 103 cultures with the 1997 and 2000 soil and root mixtures, respectively. The spores represented 30 species and 8 undescribed morphotypes in 7 genera of the Glomeromycota. The AMF most frequently found in Israeli soils were Glomus aurantium and G. constrictum, followed by G. coronatum, G. gibbosum, an undescribed Glomus 178, and Scutellospora dipurpurescens. Up to 2001, 21 species of AMF were known to occur in Israel, and this paper increases this number to 33, of which 11 are new fungi for this country. Moreover, four species, G. aurantium, G. drummondii, G. walkeri and G. xanthium, were recently described as new for science based on spores isolated from Israeli soils. Additionally, the general distribution in the world of the formally described species found in Israel was presented.
\end{abstract}

KEY WORDS: arbuscular mycorrhizal fungi, Glomeromycota, Israeli soils, occurrence.

\section{INTRODUCTION}

One of the most frequently occurring and widely distributed soil microorganisms in the world are arbuscular mycorrhizal fungi (AMF) of the phylum Glomeromycota. Until quite lately, they have been considered to associate with ca. $80 \%$ of plants of the Earth (Gianinazzi and Gianinazzi-Pearson 1986). However, the use of specific study methods, including, e.g., cultivation of rhizosphere soil samples and/or root fragments in pot trap cultures as well as molecular analyses of roots, has showed that AMF also frequently coexist with plants of, e.g., of the families Brassicaceae and Chenopodiaceae, earlier generally considered to be non-mycorrhizal (Harley and Harley 1987, 1990). This induced the Committee of the International Bank of Glomeromycota to express the supposition that "The majority of plants, strictly speaking, do not have roots; they have mycorrhizas" (http://www.kent.ac.uk/bio/beg/englishhomepage.htm).

Literature data indicate that AMF play a vital role in the life of plants. They increase, e.g., (1) the growth and nutrition of plants due to increased absorptive area of their roots by extraradical hyphae extending up to $10 \mathrm{~cm}$ outside the roots (Bieleski 1973), (2) the rate of succession (Janos 1980) and competitiveness of plants (Allen and Allen 1984; Fitter 1977), and (3) pollen production (Lau et al. 1995). Additionally, AMF (1) influence plant phenology (Allen and Allen 1986), (2) improve structure and stability of the soil through binding sand grains into aggregates by extraradical mycorrhizal fungi (Koske 1975), (3) aid cooccurring plants by transferring nutrients from better nourished plants to those of a poorer condition by hyphal bridges (Newman 1988), (4) protect plants against pathogens and nematodes (Bagyaraj 1984; Schönbeck 1978), as well as (5) alleviate the harmful effects of soil toxic substances (Turnau and Haselwandter 2002). However, the range of the improvements listed above highly depends on a species or a strain of the fungus associated with a given plant (Stahl and Christensen 1991).

Both the spore abundance of AMF and the species diversity of their spore populations may be highly influenced by, e.g., (1) a plant species and its age (Dalpé 1989; Gemma et al. 1989; Koske and Gemma 1997), (2) the composition of non-mycorrhizal soil microorganisms (Lee and Koske 1994), (3) the amount and composition of both organic and inorganic chemical substances (Koske and Gemma 
1997; Rose 1988), (4) pH (Porter et al. 1987), (5) soil compaction and its humidity (Koske and Halvorson 1981; Read 1989), as well as (6) above- and underground temperature (Koske 1987).

A few studies of the occurrence of AMF have been conducted in Israel to date. Dodd and Krikun (1984) found five species and one morphotype, and Haas and Menge (1990) nine species. Following the cultivation of field-collected rhizosphere soil and root mixtures in pot trap cultures, Błaszkowski et al. (2001b) revealed 17 species and 8 undescribed morphotypes. Among the described found species, 9 were new for this country. However, Błaszkowski et al. (2001b) examined only 49 soil and root samples collected from three sites and all but five were taken from dunes of the Mediterranean Sea adjacent to Tel-Aviv. Moreover, all the identified fungi were isolated only from the first cycle pot trap cultures containing the soil and root mixtures collected. Meanwhile, the recognition of the species diversity of AMF of a given area highly depends on the intensity of its sampling due to the aggregated occurrence of spores of these fungi (St. John and Koske 1988) and their seasonal sporulation (Gemma et al. 1989). Additionally, the absence of spores in the field or in early generations of trap cultures does not mean the absence of the arbuscular fungus inside the roots of the sampled plant. Gazey et al. (1992) concluded that sporulation of AMF begins after root colonization level is built up to a threshold value. In Stutz and Morton's (1996) investigations, $75 \%$ of the spores recognized after three propagation cycles were not detected in the first cycle. Therefore, (1) in the year 2000, next soil and root samples were collected from many sites of Israel and (2) the occurrence of AMF in the sites sampled was determined based on examination of many generations of trap cultures with soils and roots collected in both 1997 and 2000.

The aim of this paper is to present all AMF found in Israel to date.

\section{MATERIALS AND METHODS}

\section{Study sites}

In 1997, most rhizosphere soil and root samples were collected from dunes of the Mediterranean Sea extending from the Kibutz Shefayim to Tel-Aviv. Two samples were taken near Berscheva in northern Israel, two from a field located in the Negev Desert near The Volcanic Centre, and one from a meadow situated in the Jordan Valley. In 2000, all soil and root samples came from under Ammophila arenaria (L.) Link growing in different sites distributed along the bank of the Mediterranean Sea.

Collection of soil and root samples, establishment of trap cultures, and extraction of spores of AMF

Rhizosphere soils and roots of sampled plants were collected from a depth of 5-30 cm using a small garden shovel. About $100-200 \mathrm{~cm}^{3}$ samples were placed in plastic bags. After their transfer to a laboratory in Poland, they were first stored at $4^{\circ} \mathrm{C}$ for ca. one month and then used to establish trap cultures. Trap cultures were established to initiate sporulation of AM fungal species rarely sporulating in the field and species that did not produce spores at the time of collection of the field samples. The growing substra- te of the trap cultures was the field-collected material mixed with an autoclaved coarse-grained sand coming from maritime dunes adjacent to Świnoujście ( $\mathrm{pH} \mathrm{6.7;12}$ and $26 \mathrm{mg} \mathrm{L}^{-1} \mathrm{P}$ and $\mathrm{K}$, respectively; Błaszkowski 1995). The mixtures were placed into $9 \times 12.5-\mathrm{cm}$ plastic pots $\left(500 \mathrm{~cm}^{3}\right)$ and densely seeded with Plantago lanceolata $\mathrm{L}$. Plants were grown in a greenhouse at $15-30^{\circ} \mathrm{C}$ with supplemental 8-16-h lighting provided by one SON-T AGRO sodium lamp (Philips Lighting Poland S.A.) placed $1 \mathrm{~m}$ above pots. The maximum light intensity was $180 \mu \mathrm{E} \mathrm{m}^{-2} \mathrm{~s}^{-1}$ at pot level. Plants were watered 2-3 times a week. No fertilizer was applied during the growing period. Trap cultures were first harvested four months after plant emergence and then every ca. 6 month until 2006. After each harvest, the cultures were reseeded with $P$. lanceolata. Spores were extracted by wet sieving and decanting (Gerdemann and Nicolson 1963).

\section{Microscopy survey}

Morphological properties of spores and their wall structures were determined based on observation of at least 100 spores mounted in polyvinyl alcohol/lactic acid/glycerol (PVLG; Omar et al. 1979) and a mixture of PVLG and Melzer's reagent $(1: 1, \mathrm{v} / \mathrm{v})$. Spores were crushed to varying degrees by applying pressure to the cover slip and then stored at $65^{\circ} \mathrm{C}$ for $24 \mathrm{~h}$ to clear their contents from oil droplets. These were examined under an Olympus BX 50 compound microscope equipped with Nomarski differential interference contrast optics. Microphotographs were recorded on a Sony 3 CDD color video camera coupled to the microscope.

Terminology of spore structure is that suggested by Stürmer and Morton (1997) and Walker (1983). Spore colour was examined under a dissecting microscope on fresh specimens immersed in water. Nomenclature of fungi and plants is that of Walker and Trappe (1993) and Mirek et al. (1995), respectively. The authors of the fungal names are those presented at the URL web page http://www.indexfungorum.org/AuthorsOfFungalNames.htm. Specimens were mounted in PVLG on slides and deposited in the Department of Plant Pathology, University of Agriculture, Szczecin, Poland. Newly described species were deposited in the herbarium at Oregon State University in Corvallis, Oregon, USA.

Colour microphotographs of spores and mycorrhizae of the formally described species can be viewed at the URL http://www.agro.ar.szczecin.pl/ jblaszkowski/.

\section{RESULTS AND DISCUSSION}

\section{General data}

In the years 1997 and 2000, 49 and 113 rhizosphere soil and root samples were collected, respectively, in different sites of Israel. In 1997, except for two samples taken under Capsicum anпиит L. cultivated near Berscheva in northern Israel, two from under Lycopersicon esculentum Mill. grown in the Negev Desert near The Volcanic Center, and one from under Festuca rubra L. s. s. growing on an irrigated meadow in the Jordan Valley, all the other soil and root mixtures came from under Oenothera drummondii Hook. colonizing sand dunes of the Mediterranean Sea extending up to ca. $10 \mathrm{~km}$ from Tel-Aviv (Table 1). In 2000, all the 
TABLE 1. Plants examined and numbers* of soil and root samples in which the occurrence of arbuscular mycorrhizal fungi was investigated.

\begin{tabular}{ll}
\hline Plant species & Locality \\
\hline Ammophila arenaria (L.) Link & $2090-2203$ \\
\hline Oenothera drummondi Hook & $\begin{array}{c}1177-188,1190-1215,1217-1222, \\
1224,1225\end{array}$ \\
\hline Capsicum annuиm L. & 1189,1216 \\
\hline
\end{tabular}

Lycopersicon esculentum Mill. 1223

* the numbers correspond with the numbering system used by the first author of this paper.

samples collected came from under Am. arenaria growing in different dune sites adjacent to the Mediterranean Sea.

After a continuous cultivation of the rhizosphere soil and root samples collected in pot trap cultures and their examination at least twice a year, spores of AMF were found in 41 and 103 cultures with the 1997 and 2000 soil and root mixtures, respectively. The spores represented a total of 30 species and 8 undescribed morphotypes belonging to 7 genera of the Glomeromycota (Table 2). No representative of the genera Gigaspora and Paraglomus was found. The 1997 cultures hosted 20 species and 5 morphotypes in 5 genera, and those of 200020 species and 4 morphotypes in 5 genera. The fungi highly dominating in Israeli soils were members of the genus Glomus (76.1\% of all the representatives of the Glomeromycota revealed) with 15 species and 5 morphotypes and 14 species and 4 morphotypes recognized in the 1997 and 2000 cultures, respectively.

The arbuscular fungi most frequently found in trap cultures containing rhizosphere soil and root mixtures collected in 1997 were G. constrictum and an undescribed Glomus 178 (present in at least 20\% cultures), followed by Arch. trappei, G. aurantium, G. claroideum, an undescribed Glomus 130, Pac. scintillans, and Scu. dipurpurescens (found in $10-20 \%$ cultures; Table 2). The 2000 cultures most frequently hosted G. aurantium and G. constrictum, then $G$. coronatum, G. gibbosum, Glomus 178, and Scu. dipurpurescens.

Taking into account the results of the frequency of occurrence of AMF in cultures of both 1997 and 2000, the arbuscular fungi most frequently found in the Israeli soils examined were G. aurantium and $G$. constrictum, followed by G. coronatum, G. gibbosum, Glomus 178, and Scu. dipurpurescens (Table 2 ).

Of the fungal species identified in trap cultures with soils and roots collected in 1997, only Arch. trappei, G. constrictum, G. coronatum, G. geosporum, G. microcarpum, G. mosseae, and $G$. sinuosum had earlier been recorded in Israel (Dodd and Krikun 1984; Haas and Menge 1990). Although not revealed by the authors of this paper in trap cultures with the 1997 soils, other AMF found by Dood and Krikun (1984) and Haas and Menge (1990) were Ac. laevis Gerd. \& Trappe, G. calvisporum (Trappe) R.T. Almeida \& N.C. Schenck, G. fasciculatum, and G. macrocarpum Tul. \& C. Tul.

The species of AMF not revealed in the first cycle of trap cultures with soils and roots sampled in 1997 but found to sporulate in next generations of the same cultures were $D$. spurca, Scu. fulgida, Scu. pellucida, and Scu. persica.
TABLE 2. Species of arbuscular mycorrhizal fungi found in Israel.

\begin{tabular}{|c|c|c|c|}
\hline \multirow{2}{*}{ Fungal species } & \multicolumn{3}{|c|}{ Frequency of occurrence $(\%)$} \\
\hline & 1997 & 2000 & Mean \\
\hline$\overline{\text { Acaulospora paulineae }}$ & 4.1 & 6.2 & 5.5 \\
\hline Archaeospora trappei & 14.3 & & 4.3 \\
\hline Diversispora spurca & 4.1 & & 1.2 \\
\hline Entrophospora infrequens & & 1.8 & 1.2 \\
\hline G. arenarium & 2.0 & 0.9 & 1.2 \\
\hline G. aurantium & 18.4 & 47.8 & 38.9 \\
\hline G. caledonium. & 2.0 & & 0.6 \\
\hline G. claroideum & 10.2 & & 3.1 \\
\hline G. constrictum & 24.5 & 48.7 & 41.4 \\
\hline G. coronatum & 8.2 & 16.8 & 14.2 \\
\hline G. corymbiforme & & 2.7 & 1.9 \\
\hline G. drummondii & & 3.5 & 2.5 \\
\hline G. etunicatum & 2.0 & & 0.6 \\
\hline G. fasciculatum & & 0.9 & 0.6 \\
\hline G. geosporum & 4.1 & & 1.2 \\
\hline G. gibbosum & 2.0 & 11.5 & 8.6 \\
\hline G. intraradices & 4.1 & 6.2 & 5.6 \\
\hline G. microcarpum & 4.1 & 0.9 & 1.9 \\
\hline G. mosseae & 4.1 & 6.2 & 5.6 \\
\hline G. pustulatum & & 0.9 & 0.6 \\
\hline G. sinuosum & 2.0 & & 1.2 \\
\hline G. trimurales & 2.0 & & 0.6 \\
\hline G.walkeri & & 0.9 & 0.6 \\
\hline G. xanthium & 4.1 & 7.1 & 6.2 \\
\hline Glomus 126 & 8.2 & & 0.6 \\
\hline Glomus 130 & 10.2 & & 3.1 \\
\hline Glomus 139 & 2.0 & & 0.6 \\
\hline Glomus 149 & 2.0 & & 1.2 \\
\hline Glomus 163 & & 5.3 & 3.7 \\
\hline Glomus 165 & & 0.9 & 0.6 \\
\hline Glomus 178 & 20.4 & 15.0 & 16.7 \\
\hline Pacispora franciscana & & 0.9 & 0.6 \\
\hline Pacispora scintillans & 14.3 & 0.9 & 4.9 \\
\hline Scutellospora dipurpurescens & 18.4 & 13.3 & 14.8 \\
\hline S. fulgida & & 0.9 & 0.6 \\
\hline S. pellucida & & 1.8 & 1.9 \\
\hline S. persica & & 2.7 & 1.9 \\
\hline Scutellospora 179 & & & 0.6 \\
\hline
\end{tabular}

In summary, up to 2001, 21 species of AMF were known to occur in Israel (Błaszkowski et al. 2001b; Dodd and Krikun 1984; Haas and Menge 1990). This paper increases this number to 33 , of which $D$. spurca, E. infrequens, $G$. aurantium, G. corymbiforme, G. drummondii, G. pustulatum, G. trimurales, G. walkeri, Pac. franciscana, Scu. fulgida, Scu. pellucida, and Scu. persica were recorded for the first time in this country. Moreover, G. aurantium, $G$. drummondii, G. walkeri, and G. xanthium have recently been described as new species for science from spores isolated from soils of, e.g., Israel (Błaszkowski et al. 2004; Błaszkowski et al. 2006).

The finding of spores of AMF in $83.7 \%$ and $91.2 \%$ of trap cultures with rhizosphere soil and root mixtures of plants of different sites of Israel collected in the years 1997 and 2000, respectively, confirms earlier suggestions of many authors that members of the phylum Glomeromycota belong to the most commonly occurring soil microorga- 
nism in the world. However, literature data indicate that many species of AMF frequently found in the field sporulate rarely or not at all in pot cultures grown in a greenhouse. The reasons may be (1) inappropriate water and air relations (Anderson et al. 1984), $\mathrm{pH}$ (Porter et al. 1987), temperature (Koske 1987), and organic content (Koske and Gemma 1997) of pot cultures to initiate spore germination and/or to attain a minimum root colonization level needed to trigger sporulation (Gazey et al. 1992), (2) the lack or shifts in the structure of populations of non-mycorrhizal soil microorganisms reinforcing both spore germination of AMF and colonization of roots of their plant hosts (Bagyaraj 1984), and (3) the incompatibility of the AM fungal species x host plant arrangement used (Read 2002). Thus, the field samples collected by the authors of this paper could have still contained spores not listed here. Therefore, further studies are needed to reveal species of AMF sporulating in the field conditions of Israel.

The marked predominance of members of the genus Glo$m u s$ in the spore populations of AMF isolated from trap cultures with Israeli soils was not a surprise. Glomus spp. are the most frequently found arbuscular fungi in different regions of the world and fastest adapt to a wide range of physical, chemical, and biological soil conditions (Błaszkowski 1993a; Smith and Read 1997). However, the high plasticity and productivity of Glomus spp. in pot cultures may have suppressed or even eliminate other species of the Glomeromycota functioning in the field. This may explain the exceptionally low proportion of members of the genera Acaulospora and Scutellospora and the lack of species of the genera Gigaspora and Paraglomus in the spore populations of AMF isolated. Gigaspora and Scutellospora spp. prefer warm sandy soils and commonly occur in maritime dunes (Błaszkowski 1993a, b; Koske 1987). Therefore, the recognition of both the real species diversity of communities of AMF and the natural proportions of components of these communities in sites considered in the studies presented here will need the determination of the occurrence of these fungi in both field-collected soil and root samples, as well as in trap cultures with different host plants.

These studies showed that the species of AMF most frequently occurring in the Israeli soils examined were $G$. $a u$ rantium and $G$. constrictum, followed by $G$. coronatum, $G$. gibbosum, an undescribed Glomus 178, and Scu. dipurpurescens. Except for five soil and root samples taken from under cultivated plants, all the others came from dune sites extending along the bank of the Mediterranean Sea. Thus, the common occurrence of these species and their abundant sporulation in pot cultures indicate that they can be used in production of inoculum and, thereby, in protection of endangered or protected dune plants of Israel. Arbuscular mycorrhizal fungi facilitate mycorrhizal plants to colonize a site, effectively exploit its resources, and, consequently, make them more competitive for light and space (Smith and Read 1997). Moreover, native autochthonous fungal species or strains usually are best adapted to actual soil and climatic conditions and used as inoculum are more successful (Stahl and Christensen 1991).
The distribution of arbuscular mycorrhizal fungi in Israeli soils and notes on their general occurrence

$\mathrm{n}=$ number of soil samples in which a particular fungal species was found. The numbers following are those of soil and roots samples given in Table 1 and correspond with the numbering system used by the first author of this paper.

\section{Acaulospora paulinae Błaszk.}

$\mathrm{n}=9: 1218,1219,2123,2128,2134,2136,2137,2156$, 2163.

The only other report of the occurrence of Ac. paulinae in Israeli soils is that of Błaszkowski et al. (2001b) informing of its association with roots of $O$. drummondii.

Acaulospora paulinae probably has a worldwide distribution. It has been found in many cultivated and uncultivated sites of Poland (e.g., Błaszkowski 1993a, b). Jansa et al. (2002) and Oehl et al. (2004) recovered spores of $A c$. paulinae from different soils of Switzerland. Koske et al. (1997) encountered this fungus among roots of Agrostis canina Huds., A. palustis L., and Poa annua L., perennial turf species of golf greens of Rhode Island, U.S.A.

2. Archaeospora trappei (R.N. Ames \& Linderman) J.B. Morton \& D. Redecker

$\mathrm{n}=7:$ 1180, 1186, 1187, 1188, 1193, 1203, 1222.

In Israel, Arch. trappei has for the first time been recorded as Ac. trappei by Haas and Menge (1990) and then by Błaszkowski et al. (2001b).

Archaeospora trappei seems to occur in the whole world. Tadych and Błaszkowski (2000) and Błaszkowski et al. (2002) found this fungus in sand dune soils of the Słowiński National Park and the Błędowska Desert located in northern and southern Poland, respectively. This fungus has also been reported from, e.g., Australia, Brazil, Cuba, Japan, South Africa, Scotland, U.S.A. (Morton and Redecker 2001), Germany (Blaschke 1991), Switzerland (Oehl et al. 2005), and China (Gai et al. 2005). Błaszkowski (unpubl. data) isolated spores of Arch. trappei from many trap cultures with soils of Oman, Turkey, Cyprus, Italy, and France.

Spores of Arch. trappei may easily be omitted due to at least three reasons. First, they are very small and hyaline and, hence, difficult to see. Second, their wall consists of thin and delicate layers, which are easy to decompose by soil microorganisms. Third, sporulation of many AMF is seasonal (Gemma et al. 1989) and, therefore, their spores may be absent at the time of collection of field soils; most of the earlier investigations of the occurrence of AMF used only field-collected soil samples.

3. Diversispora spurca (C.M. Pfeiff., C. Walker \& Bloss) C. Walker \& Schuessler

$\mathrm{n}=1: 1197$.

Diversispora spurca has originally been discovered as $G$. spurcum in a greenhouse bed of sand used for propagation of various ornamental plants cultivated in Arizona (Pfeiffer et al. 1996). This fungus has also been found in maritime dunes of Mexico (Pfeiffer et al. 1996), Hawaii (Koske and Gemma 1996), San Miguel Island, California (Koske, pers. comm.), as well as in different other natural and cultivated ecosystems of North America, Cuba and Africa (Kennedy et al. 1999; Stutz and Morton 1996; Stutz et al. 2000), and Poland (Błaszkowski et al. 2003; Iwaniuk and Błaszkowski 2004). 
4. Entrophospora infrequens (I.R. Hall) R.N. Ames \& R.W. Schneid.

$\mathrm{n}=2: 2114,2145$.

Entrophospora infrequens has originally been described as G. infrequens Hall from spores isolated from Long Bush located in New Zealand (Hall 1977). Ames and Schneider (1979) found identical spores in two celery fields in central California. However, they did not origin blastically at the end of a sporogenous hypha as in Glomus spp. but inside the neck of a sporiferous saccule resembling that of fungi of the genus Acaulospora, whose spores develop laterally from such a saccule. This was the base to erect a new genus, Entrophospora R.N. Ames \& R.W. Schneid.

Apart from New Zealand and California, E. infrequens has also been recorded in many other regions of the U.S. (e.g., Koske and Gemma 1997; Koske and Halvorson 1989; Stahl and Christensen 1982), as well as in Canada (Boyetchko and Tewari 1993), Switzerland (Oehl et al. 2005), Poland (Błaszkowski 1993a, b), Taiwan (Wu and Chen 1986), and China (Gai et al. 2006). Additionally, Błaszkowski (unpubl. data) many times revealed this fungus in trap cultures with dune soils of Oman, Turkey, Cyprus, Italy, France, and Africa.

\section{Glomus arenarium Błaszk., Tadych \& Madej}

$\mathrm{n}=1: 1210$.

This paper confirms the first Błaszkowski's et al. (2001b) report of the presence of G. arenarium in Israeli dune soils.

Glomus arenarium has been discovered in maritime dunes of the Baltic Sea adjacent to Świnoujście in northwestern Poland (Błaszkowski et al. 2001a).

6. Glomus aurantium Błaszk., V. Blanke, C. Renker \& F. Buscot

$\mathrm{n}=62: 1203,1210,1212,1215,1219,1220,1221,1222$, $1224,2093,2102,2103,2106,2116,2117,2120,2122$, $2125,2126,2127,2130,2132,2134,2135,2136,2137$, $2140,2143,2146,2148,2149,2151,2152,2158,2161$, $2166,2168,2170,2171,2172,2173,2174,2175,2176$, $2178,2180,2182,2183,2184,2185,2186,2187,2188$, 2189, 2190, 2192, 2193, 2194, 2195, 2197, 2198, 2200.

The holotype of $G$. aurantium has been selected from spores isolated from a one-species culture established from spores recovered from a trap culture with rhizosphere soil and roots mixture of $O$. drummondii colonizing sand dunes of the Mediterranean Sea located near Tel-Aviv (Błaszkowski et al. 2004). Additionally, this fungus has been found to occur among roots of Am. arenaria growing in dunes of Majorca, Spain, Calambrone, Italy (Błaszkowski et al. 2004), Turkey, Cyprus, Greece (Błaszkowski, unpubl. data), as well as in cultivated soils of Iran (Błaszkowski, unpubl. data).

\section{Glomus caledonium (Nicol. \& Gerd.) Trappe \& Gerd.} $\mathrm{n}=1: 1225$.

The only other earlier record of G. caledonium in Israeli soils is that of Błaszkowski et al. (2001b).

Glomus caledonium has a worldwide distribution and has frequently been among the dominating species of AMF of the sites examined (Błaszkowski 1993a). However, this fungus seems to prefer more fertile soils than maritime sand dunes.
8. Glomus claroideum N.C. Schenck \& S.M. Sm.

$\mathrm{n}=5: 1181,1184,1185,1191,1201$.

Although $G$. claroideum has many times been isolated from dune soils of Israel sampled in 1997 (Błaszkowski et al. 2001b), none of the samples collected in 2000 contained spores of this fungus.

The distribution of $G$. claroideum is worldwide and it has many times been found in both maritime sand dunes (Koske 1987; Mohankumar et al. 1988; Sylvia 1986) and other cultivated and uncultivated ecosystems (Błaszkowski 2003; Jansa et al. 2002; Schenck and Smith 1982; Vestberg et al. 2005; Zhang and Wang 1992).

\section{Glomus constrictum Trappe}

$\mathrm{n}=66: 1178,1180,1182,1183,1187,1202,1208,1218$, 1219, 1220, 1222, 1223, 2090, 2091, 2092, 2093, 2105, $2112,2120,2122,2125,2133,2134,2136,2139,2140$, $2141,2144,2146,2148,2149,2151,2152,2153,2154$, $2158,2160,2161,2163,2166,2167,2168,2170,2172$, $2173,2174,2175,2176,2177,2178,2179,2181,2183$, $2185,2186,2188,2191,2192,2193,2194,2195,2196$, 2197, 2199, 2200, 2201.

The first report of the occurrence of G. constrictum in Israel is that of Haas and Menge (1990), who revealed spores of this fungus in avocado orchard soils. Błaszkowski et al. (2001b) encountered G. constrictum in 12 Israeli soil samples, of which two came from under L. esculentum.

The presence of $G$. constrictum spores in almost half the trap cultures with the 2000 Israeli soils collected by the authors of this paper confirms conclusions of, e.g., Błaszkowski (2003) that this fungus occurs in the whole world and frequently dominates in the isolated spore populations of members of the Glomeromycota. In soils of Poland, $G$. constrictum has been first in respect of frequency of occurrence and ranked third considering the proportion of its spores in populations of all spores isolated from 332 soil samples collected from 113 sites (Błaszkowski 1993a). In maritime dunes, this fungal species has been found in, e.g., Quebec, New Brunswick and New Scotia, Canada (Dalpé 1989), U.S.A. (Koske 1987, 1988), Brazil (Stürmer and Bellei 1994), and Poland (Błaszkowski 1993b, 1994).

\section{Glomus coronatum Giovann.}

$\mathrm{n}=24: 1186,1215,1220,1222,2095,2127,2128,2130$, 2146, 2151, 2152, 2157, 2158, 2159, 2164, 2165, 2166, 2175, 2176, 2178, 2182, 2193, 2195, 2197.

Dodd and Krikun (1984; Dodd, pers. comm.) were the first who identified $G$. coronatum as $G$. mosseae in soils of Israel. Błaszkowski et al. (2001b) found this fungus in four cultures with rhizosphere soils and roots of $O$. drummondii growing near Tel-Aviv.

Glomus coronatum has originally been described from spores isolated from around roots of Anacyclus radiatus Loisel colonizing a maritime sand dune system near Follonica, Tuscany, Italy (Giovanetti et al. 1991). Błaszkowski (unpubl. data) extracted spores of this fungus from many cultures with maritime dune soils of Turkey, Cyprus, Italy, France, and Africa. The only records of this fungus in nondune soils are those of Oehl et al. (2005) coming from the Upper Rine Valley extending between Basel (Switzerland), Freiburg (Germany), and Molhouse (France).

The lack of records of $G$. coronatum in ca. 3000 field soils representing different cultivated and uncultivated plants 
growing in northern Europe (Błaszkowski, pers. observ.) suggests the occurrence of this fungus to be limited to regions of a warmer climate. According to Pirozynski (1968), temperature is the most important edaphic factor regulating the distribution of fungi in general.

\section{Glomus corymbiforme Błaszk.}

$\mathrm{n}=3: 2164,2183,2191$.

Glomus corymbiforme has originally been found in maritime sand dunes of the Baltic Sea adjacent to Świnoujście in north-western Poland (Błaszkowski 1995). Additionally, this fungus has occurred in dunes of the Mediterranean Sea located near Karabucak-Tuzla, Turkey (Błaszkowski, unpubl. data).

\section{Glomus drummondii Błaszk. \& C. Renker} $\mathrm{n}=4:$ 2092, 2104, 2111, 2131 .

Glomus drummondii has recently been descried based on spores recovered from trap cultures with rhizosphere soils of plants of maritime dunes of Cyprus, Greece, Poland, Spain, and Portugal (Błaszkowski et al. 2006). Thus, the maritime dunes of Israel are the next habitats of the presence of this fungus.

\section{Glomus etunicatum W.N. Becker \& Gerd.}

\section{$\mathrm{n}=1: 1216$.}

In Israel, G. etunicatum has been associated with roots of C. annuum cultivated near Berscheva in 1997 (Błaszkowski et al. 2001b).

Glomus etunicatum is a common inhabitant of cultivated and uncultivated soils of different regions of the world (Błaszkowski 1993a).

14. Glomus fasciculatum (Thaxt.) Gerd. \& Trappe emend. C. Walker \& Koske

$\mathrm{n}=1: 2098$.

Haas and Menge (1990) were the first to record G. fasciculatum in soils of Israel.

Literature data indicate that $G$. fasciculatum occurs in the whole world and is well adapted to different soils (Błaszkowski 2003; Walker and Koske 1987). However, according to Walker and Koske (1987), many reports of this fungus may have regarded other species of AMF due to its incomplete original description.

\section{Glomus geosporum (Nicol. \& Gerd.) C. Walker} $\mathrm{n}=2: 1188,1189$.

The first report of the occurrence of G. geosporum in Israel has been that of Haas and Menge (1990), who recovered spores of this fungus from among roots of Persea americana Mill. Later, Błaszkowski et al. (2001b) revealed $G$. geosporum associated with roots of $O$. drummondii and $C$. annuum growing in dues near Tel-Aviv and a cultivated field near Berscheva in northern Israel.

Literature data suggest that G. geosporum occurs in the whole world and is adapted to conditions of different both cultivated and uncultivated soils, including conditions of maritime dunes (e.g., Błaszkowski 1993a, b; Rose 1980).

\section{Glomus gibbosum Błaszk}

$\mathrm{n}=15: 1182,2106,2107,2108,2118,2119,2125,2131$, 2154, 2155, 2157, 2160, 2161, 2176, 2187.

In Israel, G. gibbosum has for the first time been found in samples coming from under $O$. drummondii growing in dunes located near Tel-Aviv in 1997 (Błaszkowski et al. 2001b). Examination of the 2000 soil-root samples revealed this fungus to co-occur frequently with maritime dune plants of this country.

The original description of G. gibbosum has been prepared based on spores isolated from maritime dunes adjacent to Świnoujście in north-western Poland (Błaszkowski 1997). Błaszkowski (unpubl. data) also found this fungus in dunes of the Mediterranean Sea of Turkey, Cyprus, and Italy.

17. Glomus intraradices N.C. Schenck \& S.M. Sm.

$\mathrm{n}=9: 1183,1217,2098,2099,2101,2107,2112,2115$, 2196.

The Błaszkowski's et al. (2001b) finding of $G$. intraradices spores in two trap cultures with rhizosphere soils of $O$. drummondii was the first record of this fungus in Israel.

Glomus intraradices has frequently been recorded from maritime dunes of different regions of the world (see Błaszkowski et al. 2001b).

18. Glomus microcarpum Tul. \& C. Tul. $\mathrm{n}=3: 1184,1196,2142$.

In Israel, G. microcarpum has for the first time been found in soils of an avocado orchard (Haas and Menge 1990). Examination of trap cultures with rhizosphere soil and root samples of $O$. drummondii collected by the authors of this paper in 1997 and 2000 showed this fungus to be an inhabitant of dune sites of this country as well.

Glomus microcarpum is widely distributed in the word. It has earlier been encountered in many both cultivated and uncultivated sites (Błaszkowski 1993a), including maritime dunes of, e.g., the Baltic Sea, Poland (Błaszkowski 1993a, b, 1994), Madras, India (Mohankumar et al. 1988), and Italy (Puppi and Riess 1987).

19. Glomus mosseae (Nicol. \& Gerd.) Gerd. \& Trappe $\mathrm{n}=9: 1212,1223,2090,2100,2101,2105,2111,2121$, 2197.

The first report of the occurrence of G. mosseae in Israel is that of Haas and Menge (1990), who found it associated with roots of cultivated $P$. americana. Later, Błaszkowski et al. (2001b) isolated spores of this fungus from under $L$. esculentum cultivated in the Negev Desert near The Volcanic Center. The studies presented here show that G. mosse$a e$ also frequently co-occurred with maritime dune plants of Israel.

Glomus mosseae is one of the most frequently recorded AMF in different regions of the world. In Poland, this species has been the second most frequently encountered AM fungus (Błaszkowski 1993a). However, it occurred three times more frequently in cultivated than uncultivated soils.

20. Glomus pustulatum Koske, Friese, C. Walker \& Dalpé $\mathrm{n}=1: 2144$.

This paper is the first report of the presence of G. pustulatum in Israel. This fungus was revealed only in samples of dune soils collected in 2000 .

Glomus pustulatum has originally been described from spores isolated from under Am. breviligulata Fern. colonizing maritime dunes of Rhode Island, U.S.A. (Koske et al. 1986). Additionally, this fungus has been identified in maritime dunes of Canada (Dalpé 1989), Poland (Błaszkowski 
1993a, b, 1994), and India (Kulkarni et al. 1997; Mohankumar et al. 1988). There is no literature report of the occurrence of $G$. pustulatum in non-dune sites.

21. Glomus sinuosum (Gerd. \& B.K. Bakshi) R.T. Almeida \& N.C. Schenck

$\mathrm{n}=1: 1177$.

The first record of $G$. sinuosum in Israel is that from the Negev Desert (Dodd and Krikun 1984). Later, Haas and Menge (1990) found this fungus under avocado, and Błaszkowski et al. (2001b) under $O$. drummondii growing in dunes near Tel-Aviv.

Glomus sinuosum probably occurs in the whole world and is adapted to different soils, including dune soils (e.g., Almeida and Schenck 1990; Koske 1988; Wu 1993).

\section{Glomus trimurales Koske \& Halvorson} $\mathrm{n}=1: 1182$.

The only earlier finding of $G$. trimurales in Israel is that of Błaszkowski et al. (2001b). This fungus, characterized as Glomus 131, was revealed under $O$. drummondii growing in dunes near Tel-Aviv.

Glomus trimurales has originally been characterized based on spores isolated from under Abronia chamissonis var. bipinatisecta (Less.) Greene growing in maritime dunes of San Miguel Island (Koske and Halvorson 1989), although this fungus has earlier also been identified in maritime dunes of New Jersey, Maryland, and Virginia (Koske 1987). In Europe, $G$. trimurales has for the first time been encountered in dunes of the Baltic Sea adjacent to Świnoujście in north-western Poland (Błaszkowski et al. 2003).

\section{Glomus walkeri Błaszk. \& C. Renker} $\mathrm{n}=1: 2099$.

Glomus walkeri has recently been described based on spores isolated from a one-species culture established from spores isolated from a trap culture with a rhizosphere soil and root mixture of $O$. drummondii growing in dunes of the Mediterranean Sea near Tel-Aviv (Błaszkowski et al. 2006). Additionally, this fungus occurred in maritime dunes of Majorca, Spain and Calambrone, Italy (Błaszkowski et al. 2006).

24. Glomus xanthium Błaszk., V. Blanke, C. Renker \& F. Buscot

$\mathrm{n}=10: 1220,1222,2092,2108,2120,2122,2126,2130$, 2198, 2200 .

Spores of $G$. xanthium were found in trap cultures with Israeli dune soils collected in both 1997 and 2000.

Glomus xanthium has for the first time been revealed in a trap culture with a soil and root mixture taken under Xanthium cf. spinosum L. colonizing maritime dunes located near Verico in northern Greece (Błaszkowski et al. 2004). Later, this fungus has been encountered in dunes of the Mediterranean Sea adjacent to Karabucak-Tuzla, Turkey, Calambrone, Italy, and Majorca, Spain (Błaszkowski et al. 2004). Błaszkowski (unpubl. data) also found this fungus in dunes of Cyprus, France and Africa, as well as in cultivated soils of Iran. The lack of any finding of $G$. xanthium in ca. 3000 soil samples coming from northern Europe suggests it to be limited to regions of a warmer climate.

\section{Glomus 126}

$\mathrm{n}=4: 1177,1180,1182,1188$.

Spores of Glomus 126 have been revealed in trap cultures with rhizosphere soils and roots sampled in both 1997 and 2000.

The morphological characters of spores of this fungus have been presented previously (Błaszkowski et al. 2001b).

\section{Glomus 130}

$\mathrm{n}=5: 1179,1180,1182,1186,1217$.

Glomus 130 probably frequently occurs in dunes of the Mediterranean Sea of Israel as showed results of inspections of trap cultures established in both 1997 and 2000.

The description and illustrations of morphological properties of Glomus 130 spores have been presented by Błaszkowski et al. (2001b).

\section{Glomus 139}

$\mathrm{n}=1: 1219$.

Spores of Glomus 139 occurred only in the 1997 cultures.

The diagnostic characters of this fungus have earlier been presented (Błaszkowski et al. 2001b).

\section{Glomus 149}

$\mathrm{n}=1: 1198$.

Spores single in the soil; hyaline to white; globose to subglobose; (38-)50(-65) ěm diam (Fig. 1). Spore wall with two layers (layers 1 and 2). Layer 1 evanescent, at first smooth, then roughened, hyaline (0.5-)0.8(-1.2) $\mu \mathrm{m}$ thick, rarely present in mature spores. Layer 2 laminate, smooth, hyaline to white, (2.3-)6.2(-7.5) $\mu \mathrm{m}$ thick. Layers 1 and 2 not reacting in Melzer's reagent.

The species forming spores most similar to those of Glomus 149 is G. minutum Błaszk. et al. Both fungi produce colourless spores of a similar size (Błaszkowski 2000). However, most spores of $G$. minutum occur in loose clusters usually associated with its host plant roots after their washing away from the soil, whereas those of Glomus 149 always occurred singly in the soil. Additionally, the outermost spore wall layer of Glomus 149 sloughs with age, and that of G. minutum is a permanent structure.

\section{Glomus 163}

$\mathrm{n}=4: 2109,2141,2157,2174$.

Spores formed in clusters of 10 to more than 50; hyaline; globose to subglobose; (40-)65(-80) $\mu \mathrm{m}$ (Fig 2). Spore wall consists of three layers (layers 1-3; Fig. 3). Layer 1 evanescent, smooth to roughened, hyaline, $(0.5-) 0.9(-1.3)$ $\mu \mathrm{m}$ thick. Layer 2 laminate, smooth, hyaline, (2.2-)6.3(-7.0) $\mu \mathrm{m}$ thick. Layer 3 membranous, ca. 0.5-0.7 $\mu \mathrm{m}$ thick. Only layer 3 stains pinkish red in Melzer's reagent (Fig. 3).

The only other species whose spores occur in clusters and resemble in colour and size those of Glomus 163 is $G$. minutum (Błaszkowski 2000). Examination of crushed spores in a mixture of PVLG and Melzer's reagent readily separates these fungi. The spore wall of the latter species does not possess the innermost flexible spore wall layer of the former fungus.

\section{Glomus 165}

$\mathrm{n}=1: 2102$.

Spores single in the soil; red brown; (100-)150(-210) $\mu \mathrm{m}$ diam (Fig. 4). Spore wall composed of two layers (lay- 


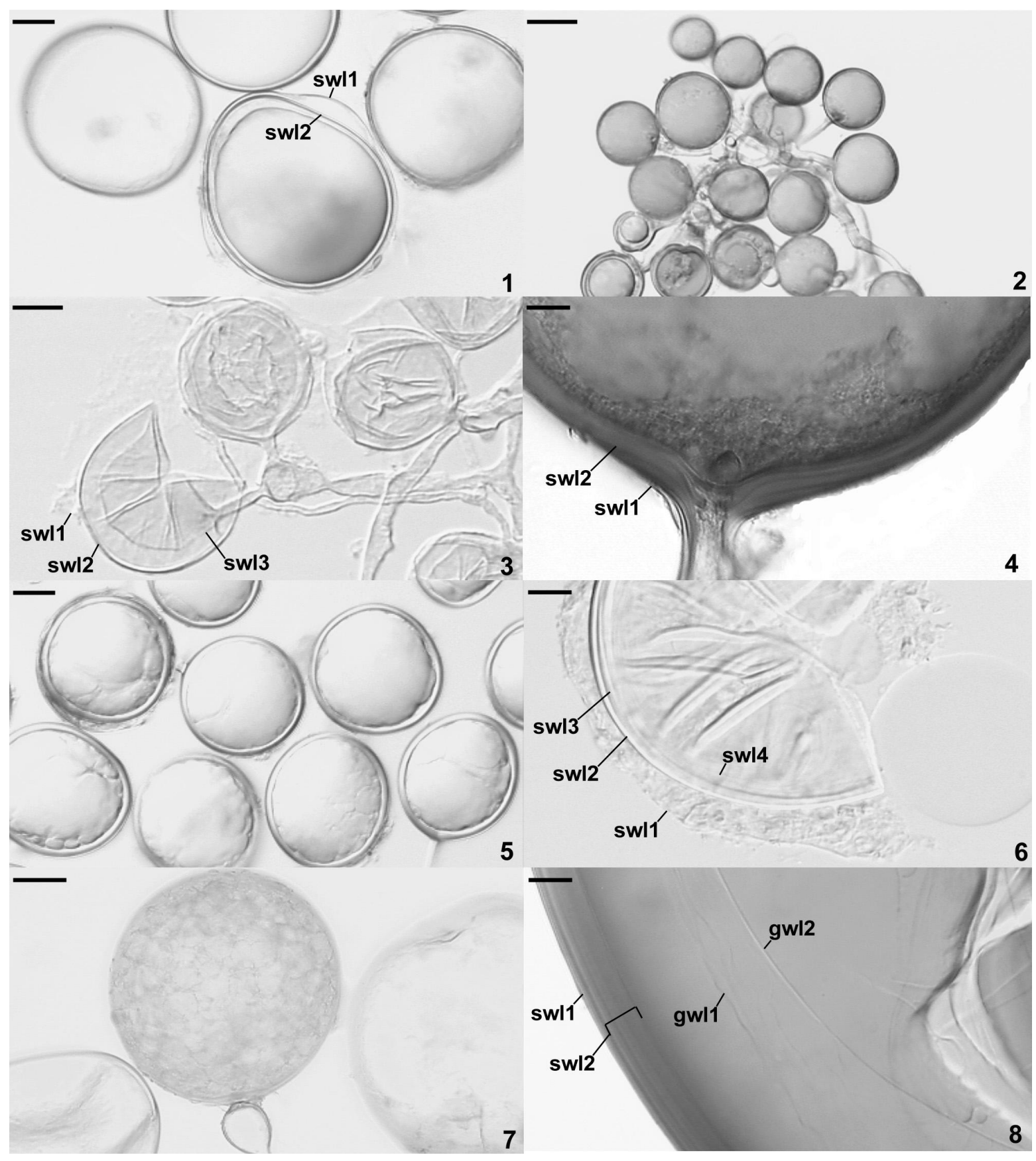

Fig. 1. Spores of Glomus 149 with spore wall layers 1 and 2 (swl1 ad swl2). Fig. 2. Cluster of spores of Glomus 163. Fig. 3. Spore wall layers 1-3 (swl 13) of Glomus 163 with layer 3 (swl3) stained in Melzer's reagent. Fig. 4. Two-layered spore wall (swl1 and swl2) of Glomus 165. Fig. 5. Spores of Glomus 178. Fig. 6. Wall layers 1-4 (swl1-4) of a crushed spore of Glomus 178. Fig. 7. Spores of Scutellospora 179. Fig. 8. Spore wall layers 1 and 2 (swl1 and swl2) and germination wall layers 1 and 2 (gwl1 and gwl2) of Scutellospora 179. Figs. 1, 5, and 7: spores mounted in lactic acid; Figs 2-4, 6, and 8: spores in a mixture of PVLG and Melzer's reagent. Bars: Figs 1, 2, 5=20 $\mu \mathrm{m} ;$ Figs 3, 4, 6, 8=10 $\mu \mathrm{m}$; Fig. $7=50 \mu \mathrm{m}$.

ers 1 and 2). Layer 1 evanescent, hyaline, (0.8-)1.5(-2.1) $\mu \mathrm{m}$ thick (Fig. 4). Layer 2 laminate, red brown, (3.5-)8.9 $(-11.0) \mu \mathrm{m}$ thick. Subtending hypha flared or slightly funnel-shaped, (14.0-)21.5(-24.5) $\mu \mathrm{m}$ wide at the spore base, occluded by a curved septum continuous with the innermost lamina of spore wall layer 2 .

The species of AMF most resembling Glomus 165 is $G$. coronatum. Both fungi form spores of a similar size and colour, as well as their wall consists of two layers of identical phenotypic properties (Błaszkowski 2003). The main character separating the two fungi is the width of their subtending hypha. The subtending hypha of G. coronatum is much wider (28.5-40.0 $\mu \mathrm{m}$ wide; Błaszkowski 2003) than that of spores of Glomus 165 (14.0-24.5 $\mu \mathrm{m}$ wide). 


\section{Glomus 178}

$\mathrm{n}=30: 1177,1179,1180,1182,1188,1194,1201,1202$, $1211,1217,1218,2117,2124,2132,2137,2139,2144$, $2153,2155,2160,2163,2170,2175,2178,2183-2185$, 2190, 2194, 2198.

Spores single in the soil; hyaline; globose to subglobose; (45.0-)65.5(-70.5) um diam (Fig. 5). Spore wall consists of four layers (layers 1-4; Fig. 6). Layer 1 evanescent, hyaline, $<0.5 \mu \mathrm{m}$ thick, usually completely sloughed even in young spores. Layer 2 permanent, hyaline, 0.5-0.8 $\mu \mathrm{m}$ thick, frequently separating from layer 3 . Layer 3 laminate, hyaline, (3.8-)5.6(-7.7) um thick. Layer 4 flexible, hyaline, usually tightly adherent to the inner surface of layer 3 . None of spore wall layers 1-3 reacts in Melzer's reagent.

Of the descried species of AMF, Glomus 178 somewhat resembles G. diaphanum J.B. Morton \& C. Walker, G. laccatum Błaszk., and Paraglomus occultum (C. Walker) J.B. Morton \& D. Redecker. Spores of all these fungi are glomoid, hyaline, and their size range more or less overlaps (Błaszkowski 2003; Morton 2002). However, only G. diaphanum has an innermost flexible spore wall layer similar to that of Glomus 178. In contrast to the four-layered spore wall of Glomus 178, that of G. diaphanum consists of three layers, lacking the spore wall layer 2 of Glomus 178.

\section{Pacispora franciscana Sieverd. \& Oehl} $\mathrm{n}=1: 2145$.

In this study, spores of Pac. franciscana have been found in one trap culture with a rhizosphere soil and roots of $\mathrm{Am}$. arenaria sampled only in 2000.

Although recently described, Pac. franciscana probably has a worldwide distribution. This fungus has originally been described from spores isolated from a grassland with olive trees growing in Umbra, Italy (Oehl and Sieverding 2004). The same mycologists also encountered this fungus in the High Alpines of Eastern Switzerland. Earlier, Pac. franciscana has probably been reported as the "white reticulate spore" by Mosse and Bowen (1968) in Australia and the "white smooth-walled azygospore" in Libyan and the Negev Desert soils by El Giahmi et al. (1976) and Dodd and Krikun (1984), respectively. In Poland, Pac. francisca$n a$ has for the first time been found associated with roots of Lupinus luteus L. cultivated in the north-west in 1985 . Later, spores of this fungus have been isolated from under many cultivated and uncultivated plant species growing in different regions of Poland (Błaszkowski, unpubl. data). Additionally, Błaszkowski (unpubl. data) found Pac. franciscana spores to occur among roots of Am. arenaria colonizing sand dunes of the Mediterranean Sea located near Karabucak-Tuzla, Turkey.

\section{Pacispora scintillans (S.L. Rose \& Trappe) Sieverd. \& Oehl}

$\mathrm{n}=8:$ 1180, 1182, 1185, 1187, 1203, 1221, 1222, 2177.

The relatively frequent presence of spores of Pac. scintillans in trap cultures established in both 1997 and 2000 indicates this fungus to be rather a common inhabitant of soils of Israel.

Pacispora scintillans has originally been described as $G$. scintillans from spores recovered from under Cercocarpus ledifolias Nutt. growing in Oregon, U.S.A. (Rose and Trappe 1980). Later, this fungus has been found in other states of the U.S. (Halvorson and Koske 1987; Walker et al. 2004), Switzerland (Oehl et al. 2004), Germany, United Kingdom, Poland, Turkey and Australia (Walker et al. 2004), as well as in China (Gai et al. 2006), where it was associated with both cultivated and uncultivated plants.

34. Scutellospora dipurpurescens J.B. Morton \& Koske $\mathrm{n}=25: 1180,1182,1187,1189,1203,1210,1216,1219$, 1221, 2097, 2108, 2118, 2130, 2138, 2140, 2143, 2152, 2157, 2158, 2166, 2171, 2172, 2185, 2186, 2198.

The results of investigations of the authors of this paper indicate $S c u$. dipurpurescens to be a frequent component of spore populations of AMF of dune soils of Israel.

Scutellospora dipurpurescens has been discovered in a rhizosphere soil of Festuca arundinacea Schreb. growing in West Virginia (Morton and Koske 1988). This fungus has also dominated or has been one of the more frequently occurring species of AMF in both maritime and inland sand dunes of Poland (Błaszkowski et al. 2001b). Additionally, $S c u$. dipurpurescens has occurred in non-dune sites of Canada (Marcel et al. 1988), Mexico (Estrada-Tores et al. 1992), and the Netherlands (Griffioen 1994).

\section{Scutellospora fulgida Koske \& C. Walker}

$\mathrm{n}=1: 2177$.

Although Scu. fulgida has not been mentioned to occur in the Israeli soils collected in 1997 (Błaszkowski et al. 2001b), later examination of next generations of the same trap cultures revealed the presence of this species.

Scutellospora fulgida has originally been described based on spores isolated from under Am. breviligulata growing in maritime dunes of Virginia, U.S.A. (Koske and Walker 1986). Other sites of its occurrence cited in the literature are maritime dunes extending from New Jersey to Virginia (Koske 1987), maritime dunes of Florida (Sylvia and Will 1988), and soils of the south and east coasts of China (Gai et al. 2006). Recently, Błaszkowski (unpubl. data) found spores of Scu. fulgida in the Mediterranean Sea dunes adjacent to Calambrone, Italy. Thus, the sites of occurrence of this fungus listed above suggest Scu. fulgida to be restricted to regions of a warmer climate.

36. Scutellospora pellucida (Nicol. \& N.C. Schenck) C. Walker \& F.E. Sanders

\section{$\mathrm{n}=1: 2092$.}

Similarly as Scu. fulgida, Scu. pellucida has not sporulated in the first generation of trap cultures with Israeli soils sampled in 1997 (Błaszkowski et al. 2001b). However, further cultivation of these cultures and examination of trap cultures with the 2000 soils revealed this species to occur in dunes of the Mediterranean Sea of Israel.

Scutellospora pellucida has been discovered in cultivated soils of northern and central Florida (Nicolson and Schenck 1979). Literature data indicate that this fungus occurs in the whole world in both cultivated and non-dune and dune natural ecosystems (e.g., Oehl et al. 2004; Koske and Gemma 1997; Sieverding 1989; Saito and Vargas 1991; Błaszkowski 1993a, b; Gai et al. 2006).

\section{Scutellospora persica (Koske \& C. Walker) C. Walker} $\&$ F.E. Sanders

$\mathrm{n}=3: 2177,2189,2190$.

Scutellospora persica is the third species not revealed in the first cycle of trap cultures with soils collected in 1997, 
but this fungus was found to sporulate in both older cultures with the 1997 soils and the first generation of cultures representing the 2000 year.

The original description of Scu. persica has been prepared based on spores isolated from a barrier dune located in New Jersey, U.S.A., although this fungus has also occurred in coastal sand dunes of the east coast of the U.S.A. from Massachusetts to Virginia (Koske and Walker 1985). Apart from the U.S., this fungal species has also been recorded in dunes and other soils in Brazil (Grandi and Trufem 1991), Italy (Puppi et al. 1986), Poland and Greece (Błaszkowski and Tadych 1997), as well as in China (Gai et al. 2006).

\section{Scutellospora 179}

\section{$\mathrm{n}=1: 2183$.}

Spores single in the soil; capsicum red to red brown; 250-400 um diam (Fig. 7). Spores with two walls, a spore wall and an inner germination wall. Spore wall consists of two layers (layers 1 and 2; Fig. 8). Layer 1 permanent, yellow brown, 0.5-0.9 $\mu \mathrm{m}$ thick, ornamented with small warts, 0.5-0.8 $\mu \mathrm{m}$ high. Layer 2 laminate, capsicum red to red brown, 4.0-11.5 $\mu \mathrm{m}$ thick. Germination wall composed of two hyaline layers (layers 1 and 2; Fig. 8). Layer 1 flexible, $0.5-0.8 \mu \mathrm{m}$ thick, frequently adherent to layer 2 . Layer 2 flexible to semi-flexible, 1.0-1.8 $\mu \mathrm{m}$ thick, staining pinkish red in Melzer's reagent.

Spores of Scutellospora 179 are most reminiscent of those of Scu. persica (Koske \& C. Walker) C. Walker \& F.E. Sanders in size and in having a warty outer spore wall layer forming the spore surface. The only character distinguishing the two fungi is colour of their spores. Spores of Scutellospora 179 are darker (capsicum red to red brown) than those of Scu. persica (sunflower yellow (4A7) to apricot yellow; Błaszkowski 2003).

\section{ACKNOWLEDGMENT}

This study was supported in part by The Committee of Scientific Researches, grant no. 2 P04C 04128.

\section{LITERATURE CITED}

ALLEN E.B., ALLEN M.F. 1984. Competition between plants of different successional stages: mycorrhizae as regulators. Can. J. Bot. 62: 2625-2629.

ALLEN E.B., ALLEN M.F. 1986. Water relations of xeric grasses in the field: interactions of mycorrhizae and competition. New Phytol. 104: 559-571.

ALMEIDA R., SCHENCK N.C. 1990. A revision of the genus Sclerocystis (Glomaceae, Glomales). Mycologia 82: 703-714.

AMES R.N., SCHNEIDER R.W. 1979. Entrophospora, a new genus in the Endogonaceae. Mycotaxon 8: 347-352.

ANDERSON R.C., LIBERTA A.E., DICKMAN L.A. 1984. Interaction of vascular plants and vesicular-arbuscular mycorrhizal fungi across a soil moisture-nutrient gradient. Oecologia 64: 111-117.

BAGYARAJ D.J. 1984. Biological interaction with VA mycorrhizal fungi. In: VA mycorrhiza. Powell C.Ll., Bagyaraj D.J. (eds). CRS Press, Inc. Boca Raton, Florida, pp. 132-146.

BIELESKI R.L. 1973. Phosphate pools, phosphate transport and phosphate availability. Ann. Rev. Plant Physiol.: 225-252.

BLASCHKE H. 1991. Multiple mycorrhizal associations of individual calcicole host plants in the alpine grass-heath zone. Mycorrhiza 1: 31-34.
BŁASZKOWSKI J. 1993. Comparative studies of the occurrence of arbuscular fungi and mycorrhizae (Glomales) in cultivated and uncultivated soils of Poland. Acta Mycol. 28: 93-140.

BŁASZKOWSKI J. 1993. The occurrence of arbuscular fungi and mycorrhizae (Glomales) in plant communities of maritime dunes and shores of Poland. Bul. Pol. Acad. Sci. Biol. Sci. 41: 377-392.

BŁASZKOWSKI J. 1994. Arbuscular fungi and mycorrhizae (Glomales) of the Hel Peninsula, Poland. Mycorrhiza 5: 71-88.

BŁASZKOWSKI J. 1995. Glomus corymbiforme, a new species in Glomales from Poland. Mycologia 87: 732-737.

Błaszkowski J. 1997. Glomus gibbosum, a new species from Poland. Mycologia 89: 339-345.

BŁASZKOWSKI J. 2000. Glomus minutum, a new species in Glomales (Zygomycetes) from Poland. Mycotaxon 76: 187-195.

BŁASZKOWSKI J. 2003. Arbuscular mycorrhizal fungi (Glomeromycota), Endogone, and Complexipes species deposited in the Department of Plant Pathology, University of Agriculture in Szczecin, Poland. http://www.agro.ar.szczecin.pl/ jblaszkowski/.

BŁASZKOWSKI J., ADAMSKA I., CZERNIAWSKA B. 2003. Glomus claroideum and G. spurcum, arbuscular mycorrhizal fungi (Glomeromycota) new for Poland and Europe, respectively. Acta Soc. Bot. Pol. 72: 149-156.

BŁASZKOWSKI J., BLANKE V., RENKER C., BUSCOT F. 2004. Glomus aurantium and $G$. xanthium, new species in Glomeromycota. Mycotaxon 90: 447-467.

BŁASZKOWSKI J., RENKER C., BUSCOT F. 2006. Glomus drummondii and G. walkeri, two new species of arbuscular mycorrhizal fungi (Glomeromycota). Mycol. Res. 110: 555-566

BŁASZKOWSKI J., TADYCH M. 1997. Scutellospora persica (Glomales, Zygomycetes), an arbuscular mycorrhizal fungus new to the Mycota of Poland. Mycotaxon 65: 379-390.

BŁASZKOWSKI J., TADYCH M., MADEJ T. 2001. Glomus arenarium, a new species in Glomales (Zygomycetes). Acta Soc. Bot. Pol. 70: 97-101.

BŁASZKOWSKI J., TADYCH M., MADEJ T. 2002. Arbuscular mycorrhizal fungi (Glomales, Zygomycota) of the Błędowska Desert. Acta Soc. Bot. Pol. 71: 71-85.

BŁASZKOWSKI J., TADYCH M., MADEJ T., ADAMSKA I., IWANIUK A. 2001. Arbuscular mycorrhizal fungi (Glomales, Zygomycota) of Israeli soils. Mat. II Polsko-Izraelskiej Konf. Nauk. nt. "Gospodarowanie zasobami wodnymi i nawadnianie roślin uprawnych". Przegląd naukowy Wydz. Inż. Kształt. Środ. 22: 8-27.

BOYETCHKO S.M., TEWARI J.P. 1993. Occurrence of vesicular-arbuscular mycorrhizal fungi in Alberta, Canada. Z. Naturforsch. 48c: 923-929.

DALPÉ Y. 1989. Inventaire et repartition de la flore endomycorhizienne de dunes et de rivages maritimes du Quebec, du Nouveau-Brunswick et de la Nouvelle-Ecosse. Naturaliste can. (Rev. Ecol. Syst.) 116: 219-236.

DODD J.C., KRIKUN J. 1984. Observations on endogonaceous spores in the Negev Desert (Israel). Trans. Br. Mycol. Soc. 82: 536-540

EL-GIAHMI A.A., NICOLSON T.H., DAFT M.J. 1976. Endomycorrhiza fungi from Libyan soils. Trans. Br. Mycol. Soc. 67: 164-169.

ESTRADA-TORRES A., VARELA L., HERNANDEZ-CUEVAS L., GAVITO M.E. 1992. Algunos hongos micorrizicos arbusculares del estado de Tlaxcala, México. Rev. Mex. Mic. 8: $85-110$.

FITTER A.H. 1977. Influence of mycorrhizal infection on competition for phosphorus and potassium by two grasses. New Phytol. 79: 119-125.

GAI J.P., CHRISTIE P., FENG G., LI X.L. 2005. Twenty years of research on biodiversity and distribution of arbuscular mycorrhizal fungi in China: a review. Mycorrhiza http://www. springerlink.com. 
GAZEY C., ABBOTT L.K., ROBSON A.D. 1992. The rate of development of mycorrhizas affects the oneset of sporulation and production of external hyphae by two species of Acaulospora. Mycol. Res. 96: 643-650.

GEMMA J.N., KOSKE R.E., CARREIRO M. 1989. Seasonal dynamics of selected species of VA mycorrhizal fungi in a sand dune. Mycol. Res. 92: 317-321.

GERDEMANN J.W., NICOLSON T.H. 1963. Spores of mycorrhizal Endogone species extracted from soil by wet sieving and decanting. Trans. Brit. Mycol. Soc. 46: 235-244.

GIANINAZZI S., GIANINAZZI-PEARSON V. 1986. Progress and headaches in endomycorrhiza biotechnology. Symbiosis 2: 139-149.

GIOVANNETTI M., AVIO L., SALUTINI L. 1991. Morphological, cytochemical, and ontogenetic characteristics of a nnew species of vesicular-arbuscular mycorrhizal fungus. Can. J. Bot. 69: 161-167.

GRANDI R.A.P., TRUFEM S.F.B. 1991. Fungos micorrizos vesiculo-arbusculares em Marantaceae cultivadas no Instituto de Botanica, Sao Paulo, SP. Revta brasil. Bot. 14: 89-95.

GRIFFIOEN W.A.J. 1994. Characterization of a heavy metal-tolerant endomycorrhizal fungus from the surroundings of a zic refinnery. Mycorrhiza 4: 197-200.

HAAS J.H., MENGE J.A. 1990. VA-mycorrhizal fungi and soil characteristics in avocado (Persea americana Mill.) orchard soils. Plant and Soil 127: 207-212.

HALL I.R. 1977. Species and mycorrhizal infections of New Zealand Endogonaceae. Trans. Br. Mycol. Soc. 68: 341-356.

HALVORSON W.L., KOSKE R.E. 1987. Mycorrhizae associated with an invasion of Erechtites glomerata (Asteraceae) on San Miguel Island, California. Madrono 34: 260-268.

HARLEY J.L., HARLEY E.L. 1987. A check-list of mycorrhiza in the British flora. New Phytol. 105: 1-102.

HARLEY J.L., HARLEY E.L. 1990. A check-list of mycorrhiza in the British flora - second addenda and errata. New Phytol. 115: 699-711.

IWANIUK A., BŁASZKOWSKI J. 2004. Arbuscular fungi and mycorrhizae of agricultural soils of the Western Pomerania. Part I. Occurrence of arbuscular fungi and mycorrhizae. Acta Mycol. 39(1): 59-84.

JANOS D.P. 1980. Mycorrhizae influence tropical succession. Biotropica 12: 56-64.

JANSA J., MOZAFAR A., ANKEN T., RUH R., SANDERS I.R., FROSSARD E. 2002. Diversity and structure of AMF communities as affected by tillage in a temperate soil. Mycorrhiza 12: 225-234

KENNEDY L.J., STUTZ J.C., MORTON J.B. 1999. Glomus eburneum and $G$. luteum, two new species of arbuscular mycorrhizal fungi, with emendation of $G$. spurcum. Mycologia 91: 1083-1093.

KOSKE R.E. 1975. Endogone spores in Australian sand dunes. Can. J. Bot. 53: 668-672.

KOSKE R.E. 1987. Distribution of VA mycorrhizal fungi along a latitudinal temperature gradient. Mycologia 79: 55-68

KOSKE R.E. 1988. Vesicular-arbuscular mycorrhizae of some Hawaiian dune plants. Pac. Sci. 42: 217-229.

KOSKE R.E., FRIESE C., WALKER C., DALPÉ Y. 1986. Glomus pustulatum: a new species in the Endogonaceae. Mycotaxon 26: 143-149.

KOSKE R.E., GEMMA J.N. 1996. Arbuscular mycorrhizal fungi in Hawaiian sand dunes: Island of Kaua'i. Pacific Sci. 50: 36-45.

KOSKE R.E., GEMMA J.N. 1997. Mycorrhizae and succession in plantings of beachgrass in sand dunes. Am. J. Bot. 84: 118-130.

KOSKE R.E., GEMMA J.N., JACKSON N. 1997. Mycorrhizal fungi associated with three species of turfgrass. Can. J. Bot. 75: 320-332.

KOSKE R.E., HALVORSON W.L. 1981. Ecological studies of vesicular-arbuscular mycorrhizae in a barrier sand dune. Can. J. Bot. 59: 1413-1422.
KOSKE R.E., HALVORSON W.L. 1989. Mycorrhizal associations of selected plant species from San Miguel island, Channel Islands national Park, California. Pacific Sci. 43: 32-40.

KOSKE R.E., WALKER C. 1985. Species of Gigaspora (Endogonaceae) with roughened outer walls. Mycologia 77: 702-720.

KOSKE R.E., WALKER C. 1986. Species of Scutellospora (Endogonaceae) with smooth-walled spores from maritime sand dunes: two new species and a redescription of the spores of Scutellospora pellucida and Scutellospora calospora. Mycotaxon 27: 219-235

KULKARNI S.S., RAVIRAJA N.S., SRINDHAR K.R. 1997. Arbuscular mycorrhizal fungi of tropical dunes of west coast of India. J. Coast Res. 13: 931-936

LAU T.-C., LU X., KOIDE R.T., STEPHENSON A.G. 1995. Effects of soil fertility and mycorrhizal infection on pollen production and pollen grain size of Cucurbita pepo (Cucurbitaceae). Plant, Cell Environm. 18: 169-177.

LEE P.J., KOSKE R.E. 1994. Gigaspora gigantea: parasitism of spores by fungi and actinomycetes. Mycol. Res. 98: 458-466.

MARCEL G.A., VAN DER HEIDEN M.G. A., KLIRONOMOS J.N., URSIC M., MOUTOGLIS P., STREITWOLF-ENGEL R., BOLLER T., WIEMKEN A., SANDERS I.R. 1988. Mycorrhizal fungal diversity determines plant biodiversity, ecosystem variability and productivity. Nature 396: 69-72.

MIREK Z, PIĘKOŚ-MIRKOWA H., ZAJĄ A., ZAJĄC M. 1995. Vascular plants of Poland. A Checklist. Polish Botanical Studies, Guidebook 15, Kraków, 303 pp.

MOHANKUMAR V., RAGUPATHY S., NIRMALA C.B., MAHADEVAN A. 1988. Distribution of vesicular arbuscular mycorrhizae (VAM) in the sandy beach soils of Madras coast. Cur. Sci. 57: 367-368.

MORTON J.B. 2002. International Culture Collection of (Vesicular) Arbuscular Mycorrhizal Fungi. West Virginia University: http://www.invam.caf.wvu.edu/.

MORTON J.B., KOSKE R.E. 1988. Scutellospora dipurpurascens, a new species in the Endogonaceae from West Virginia. Mycologia 80: 520-524.

MORTON J.B., REDECKER D. 2001. Two families of Glomales, Archaeosporaceae and Paraglomaceae, with two new genera Archaeospora and Paraglomus, based on concordant molecular and morphological characters. Mycologia 93: 181-195.

MOSSE B., BOWEN G.D. 1968. The distribution of Endogone spores in some Australian and New Zealand soils, and in an experimental field soil at Rothamsted. Trans. Br. Mycol. Soc. 51: 485-492.

NEWMAN E.I. 1988. Mycorrhizal links between plants: their functioning and ecological significance. Adv. Ecol. Res. 18: 243-270.

NICOLSON T.H., SCHENCK N.C. 1979. Endogonaceous mycorrhizal endophytes in Florida. Mycologia 71: 178-198.

OEHL F., SIEVERDING E. 2004. Pacispora, a new vesicular arbuscular mycorrhizal fungal genus in the Glomeromycetes. J. Appl. Bot. 78: 72-82.

OEHL F., SIEVERDING E., INEICHEN K., RIS E.-A., BOLLER T., WIEMKEN A. 2005. Community structure of arbuscular mycorrhizal fungi at different soil depths in extensively and intensively managed agroecosystems. New Phytol. 165: 273-283.

OEHL F., SIEVERDING E., MADER P., DUBOIS D., INEICHEN K., BOLLER T., WIEMKEN A. 2004. Impact of longterm conventional an organic farming on the diversity of arbuscular mycorrhizal fungi. Oecologia 138: 574-583.

OMAR M.B., BOLLAN L., HEATHER W.A. 1979. A permanent mounting medium for fungi. Bull. Br. Mycol. Soc. 13: 31-32.

PFEIFFER C.M., WALKER C., BLOSS H.E. 1996. Glomus spurcum: a new endomycorrhizal fungus from Arizona. Mycotaxon 59: 373-382.

PIROZYNSKI K.A. 1968. Geographical distribution of fungi. In: The fungi. Ainsworth G.C., Sussman A.S. (eds). Academic Press, New York, pp. 487-504. 
PORTER W.M., ROBSON A.D., ABBOTT L.K. 1987. Field survey of the distribution of vesicular-arbuscular mycorrhizal fungi in relation to soil pH. J. Appl. Ecol. 24: 659-662.

PUPPI G., RIESS S. 1987. Role and ecology of VA mycorrhizae in sand dunes. Angew. Botanik 61: 115-126.

PUPPI G., CHIAPPERI F., TABACCHINI P. 1986. Endogonacee del litorale tirrenico. Mic. Ital. 2: 7-14.

READ D.J. 1989. Mycorrhizas and nutrient cycling in sand dune ecosystems. Proc. Royal Soc. Edinburg 96B: 89-110.

READ D.J. 2002. An ecological point of view on arbuscular mycorrhizal research. In: Mycorrhizal technology in agriculture. From genes to bioproducts. Gianinazzi S., Schüepp H., Barea J.M., Haselwandter K. (eds). Birkhäuser Verlag, Basel, Boston, Berlin, pp. 129-136.

ROSE S.L. 1980. Mycorrhizal associations of some actinomycete nodulated nitrogen-fixing plants. Can. J. Bot. 58: 1449-1454.

ROSE S. 1988. Above and belowground community development in a maritime sand dune ecosystem. Plant and Soil 109: 215-226.

ROSE S., TRAPPE J.M. 1980. Three new endomycorrhizal Glomus spp. associated with actinorrhizal shrubs. Mycotaxon 10: 413-420

SAITO M., VARGAS R. 1991. Vesicular-arbuscular mycorrhizal fungi in some humus-rich Ando soils of Japan. Soil Microorg. 38: $3-15$

SCHENCK N.C., SMITH G. 1982. Additional new and unreported species of mycorrhizal fungi (Endogonaceae) from Florida. Mycologia 74: 77-92.

SCHÖNBECK F. 1978. Einfluss der endotrophen Mykorrhiza auf die Krankheitsresistenz höherer Pflanzen. Z. PflKrankh. PflSchutz 85: 191-196.

SIEVERDING E. 1989. Ecology of VAM fungi in tropical ecosystesm. Agric., Ecosyst. and Environ. 29: 369-390.

SMITH S.E., READ D.J. 1997. Mycorhizal symbiosis. Academic Press. Harcourt Brace \& Company, Publishers. San Diego, London, New York, Boston, Sydney, Tokyo, Toronto.

ST. JOHN T.V., KOSKE R.E. 1988. Statistical treatment of endogonaceous spore counts. Trans. Br. Mycol. Soc. 91: 117-121.

STAHL P.D., CHRISTENSEN M. 1982. Mycorrhizal fungi associated with Bouteloua and Agropyron in Wyoming sagebrushgrasslands. Mycologia 74: 877-885.

STAHL P.D., CHRISTENSEN M. 1991. Population variation in the mycorrhizal fungus Glomus mosseae: breath of endomycorrhizal tolerance. Mycol. Res. 95: 300-307.

STURMER S.L., BELLEI M.M. 1994. Composition and seasonal variation of spore populations of arbuscular mycorrhizal fungi in dune soils on the island of Santa Catarina, Brazil. Can. J. Bot. 72: 359-363.

STÜRMER S.L., MORTON J.B. 1997. Developmental patterns defining morphological characters in spores of four species in Glomus. Mycologia 89: 72-81.
STUTZ J.C., MORTON J.B. 1996. Successive pot cultures reveal high species richness of arbuscular mycorrhizal fungi in arid ecosystems. Can. J. Bot. 74: 1883-1889.

STUTZ J.C., COPEMAN R., MARTIN C.A., MORTON J.B. 2000. Patterns of species composition and distribution of arbuscular mycorrhizal fungi in arid regions of southwestern North America and Namibia, Africa. Can. J. Bot. 78: 237-245.

SYLVIA D.M. 1986. Spatial and temporal distribution of vesicular-arbuscular mycorrhizal fungi associated with Uniola paniculata in Florida foredunes. Mycologia 78: 728-734.

SYLVIA D.M., WILL M.E. 1988. Establishment of vesicular-arbuscular mycorrhizal fungi and other microorganisms on a beach replenishment site in Florida. Appl. Environ. Microbiol. 54: 348-352.

TADYCH M., BŁASZKOWSKI J. 2000. Arbuscular fungi and mycorrhizae (Glomales) of the Słowiński National Park, Poland. Mycotaxon 74: 463-483.

TURNAU K., HASELWANDTER K. 2002. Arbuscular mycorrhizal fungi, an essential component of soil microflora in ecosystem restoration. In: Mycorrhizal technology in agriculture. Gianinazzi S., Schüepp H., Barea J.M., Haselwandter K. (eds). Birkhauser Verlag/Switzerland, pp. 137-149.

VESTBERG M., SAARI K., KUKKONEN S., HURME T. 2005. Mycotrophy of crops in rotation and soil amendment with peat influence the abundance and effectiveness of indigenous arbuscular mycorrhizal fungi in field soil. Mycorrhiza 15: 447-458.

WALKER C. 1983. Taxonomic concepts in the Endogonaceae: spore wall characteristics in species descriptions. Mycotaxon 18: 443-455

WALKER C., BŁASZKOWSKI J., SCHWAZOTT D., SCHÜßLER A. 2004. Gerdemannia gen. nov., a genus separated from Glomus, and Gerdemanniaceae fam. nov., a new family in the Diversisporales based on the former Glomus scintillans. Mycol. Res. 108(6): 707-718.

WALKER C., KOSKE R.E. 1987. Taxonomic concepts in the Endogonaceae: IV. Glomus fasciculatum redescribed. MycotaXon 30: 253-262.

WALKER C., TRAPPE J.M. 1993. Names and epithets in the Glomales and Endogonales. Mycol. Res. 97: 339-344.

WU C.-G. 1993. Glomales of Taiwan: IV. A monograph of Sclerocystis (Glomaceae). Mycotaxon 59: 327-349.

WU C.-G., CHEN Z.-C. 1986. The Endogonaceae of Taiwan. I. A preliminary investigation on Endogonaceae of bambooo vegetation at Chi-Tou areas, Central Taiwan. Taiwania 31: 65-88.

ZHANG M.-Q., WANG Y.-S. 1992. Eight species of VA mycorrhizal fungi from Northern China. Acta mycol. Sinica. 2: 258-267 . 